\title{
IDENTITIES, CULTURAL MITIGATION AND ETHNIC MINORITY INTERPRETERS
}

\author{
Sangi GURUNG \\ Translation Programme \\ Hong Kong Baptist University (HKBU) \\ Hong Kong \\ sangigurung@yahoo.com
}

\begin{abstract}
This paper explores the identity construction of ethnic minority (EM) interpreters in Hong Kong and the way cultural differences are incorporated into interpreting in legal settings. The linkage between the two key themes under this study is intertwined by a proposition that an EM interpreter is able to identify cultural differences at work because of his/her close affiliation with the culture, language and ethnicity. In examining the formation of EM interpreters' professional identities, the intricate interplay of the interpreters' perceptions, knowledge, native values and beliefs on the one hand and institutional mechanisms/mainstream practice on the other, will be studied. Based on the theoretical framework of Jenkins' internal-external dialectic of identification developed in Social Identity (2004) and Rethinking Ethnicity (2008), I will integrate Neuliep's (2009) contextual approach of intercultural communication to examine the integration of cultural differences in interpreters' interpretation. The research methods primarily used in this project are Milroy's $(1987,2003)$ approach of social networking and critical ethnography (Madison 2005). Social networking has been used as an overarching theme in navigating contacts for collecting data and analysing the network dynamics that influence interpreting practice. Likewise, critical ethnography has been used as a tool to investigate how different power structures impact legal interpreting practice. Need for proper assessment, accreditation, professional development opportunities and the code of ethics have emerged as overlapping topics in the process of data collection. As interpreting practice in EM languages in Hong Kong is still relatively unexplored, the project aims at providing viable recommendations to the development of the interpreting profession in legal settings, in particular in Hong Kong.
\end{abstract}

Key words: Identity, culture, context, social networking and critical ethnography

पहिचानहरु, सांस्कृतिक राहत तथा अल्पसंख्यक अनुवादकहरु

\begin{abstract}
सार यस लेखले हड़कड्नमा अल्पसंख्यक अनुवादकहरुको पहिचान निर्माण र कानूनी परिवेशहरुमा सांस्कृतिक भिन्नता अनुवादमा सम्मिलित गर्ने सम्बन्धमा खोज गर्दछ। यस अध्ययन अन्तगत यी दुइ मूल विषयहरु बीचको संयोजन यस प्रस्तावद्धारा बाँधिएको छ कि एक अल्पसंख्यक अनुवादकले उसको संस्कृति, भाषा तथा जाति या समहससंगको आवद्धताका कारणले काममा सांस्कतिक विभिन्नता पत्ता लगाउन सक्दछ। अल्पसंख्यक अनुवादकहरुको ब्यवसायिक पहिचानहरुको निर्माणको परिक्षण गर्दा, एका तिर अनुवादकको सोच, ज्ञान, मूल मान्यता एवंम विश्वासहरु र अर्का तिर संस्थागत संयन्त्र/मूलधारमा रहेको अभ्यास बीचको जटिल पारस्परिक प्रभावलाई अध्ययन गरिनेछ। सोसियल आइडेन्टीटी (२००४) र रीथीड़किड्न एथेनोसीटीमा (२००६) विकसित जेन्किसको पहिचान सम्बन्धि बाह्य भित्री बहस सम्बन्धि सैद्धान्तिक संरचनाको आधारमा म न्युलेप (२००९)को अन्तरसांस्कृतिक संवादको प्रासंगिक पद्धति अनुवादकको अनुवादमा सांस्कृतिक विभिन्नताको जाँच गर्नका निम्ति समायोजना गर्नेह्छु। यस परियोजनामा प्रयोग भएका मुख्य अनुसन्धानका प्रकयाहरु मिल्रोईका (१९६९, २००३) सामाजिक सन्जाल र म्याडीसनका (२००४) क्रिटीकल एथेनोग्राफी मूल रुपमा प्रयोग गरिएका छन। विवरण संकलन गर्न सामाजिक सन्जाललाई सबै समेटीने विषयको रुपमा सर्प्पकमा रहेका ब्यक्तिहरुलाई पहिल्याउन र सन्जालको परिवर्तित गतिसिल्ताले अनुवाद सम्बन्धि अभ्यास माथि पर्न जाने प्रभाव विश्लेषण गर्न प्रयोग गरिएको छ। त्यसै गरी कानूनी अनुवाद सम्बन्धि अभ्यासलाई कसरी विभिन्न शक्ति संरचनाले असर पार्दछ भान अनुसन्धान गर्ने साधनको रुपमा क्रिटीकल एथेनोग्राफीलाई प्रयोग गरिएको छ। उचित परिक्षण, आधिकारीक मान्यता, ब्यवसायिक विकासका अवसरहरु र आचार संहिताको आवश्यक्ता विवरण संकलनको प्रकफामा दोहोरीएका विषयहरुको रुपमा आएका छन। हड़कड़्नमा अल्पसंख्यक भाषाहरुमा अनुवाद सम्बन्धि अभ्यासमा त्यति साहो खोज नगरिएको कारणले, यस परियोजनाले विशेष गरी हड्नकड्नमा कानूनी परिवेशहरुमा अनुवाद सम्बन्धि ब्यवसायलाई विकास गर्ने ब्यवहारिक सिफारिशहरु उपलब्ध गराउने लक्ष्य राख्दछ।
\end{abstract}

मुख्य शब्दहरु. पहिचानहरु, संस्कृति, परिवेश, सामाजिक संजाल तथा क्रिटीकल एथनोग्राफी

TOŻSAMOŚĆ, OGRANICZENIA KULTUROWE ORAZ TLUMACZE MNIEJSZOŚCI ETNICZNYCH

Abstrakt: W artykule zostaje podjęta analiza tożsamości etnicznych tłumaczy w Hong Kongu. Zaprezentowano również sposób w jaki różnice kulturowe są adaptowane w interpretacji prawniczej. Metoda badawcza zaprezentowana w pracy 
opiera się na podejściu Milroy’a (1987, 2003) oraz Mdisona (2005). Media społecznościowe zastały użyte do zebrania danych potrzebnych do analizy. W procesie zbierania danych: potrzeba właściwej oceny, akredytacja, możliwości zawodowe czy kodeks etyki pojawiały się najczęściej. Stosunkowo, temat ten nie był podejmowany. Należałoby go poszerzyć w najbliższej przyszłości. Praca miała za zadanie zapewnienie realnych zaleceń dla rozwoju tłumacza ustnego prawniczego w Hong Kongu.

Słowa kluczowe: tożsamość; kultura; kontekst; social networking oraz krytyczna etnografia

\section{Background: existing issues}

Over the past few decades Hong Kong has developed a history of using Ethnic Minority (EM) or foreign language interpreters, also known as part-time interpreters, in legal settings, both in the courts and law-enforcement agencies. This paper consistently uses EM language interpreters (hereafter referred to as interpreters,) as opposed to foreign language interpreters, as EM groups not only denote a smaller number in proportion to the mainstream population, but also signify indifference (Erni and Leung 2014) to their existence by the mainstream society. As EM groups, interpreters' professional needs go unheeded, the quality of service compromised and the interpreting service seen as what Herbert (1952) referred to be a "necessary evil". "EM" is used not merely because it is categorised or labelled by the dominant society, it also represents the ability of the groups to claim or re-assert their own images and identities in terms of self-determination, self-identification and self-esteem (Song 2003). The following paragraphs outline the situation and underlying issues.

\subsection{Current practice}

As at June 2013, according to information provided by the Judiciary ${ }^{1}$, there were 337 registered parttime interpreters who provided interpreting and translation services involving foreign languages (other than Chinese and English.) They interpreted a total of 57 languages and dialects, with some capable of interpreting more than one language/dialect. Among the total number of interpreters, 206 interpreted 21 Asian (including Middle Eastern) languages, 16 interpreted 8 African languages, 41 interpreted 9 European languages and 171 interpreted 19 Chinese dialects. This record excludes in-house (full time) Judiciary interpreters, who interpret in the official languages, which are Cantonese, Mandarin and English, in addition to some Chinese dialects. Interpreters registered with the Judiciary interpret, translate and certify all kinds of documents used in legal proceedings.

Due to Hong Kong's colonial history, escalating migration trends, limited job opportunities for EM groups and flexible working hours, interpreting work in Hong Kong has attracted candidates from many ethnic minority groups who are bilingual or multilingual and have diverse backgrounds and qualifications, ranging from secondary education to university degrees. The majority of EM interpreters with the Judiciary became interpreters inadvertently, as a result of searching for viable job opportunities in Hong Kong; work that emerged out of necessity, both for the service users as well as the interpreters.

EM language interpreters are recruited by the Judiciary and a master list of interpreters is created by it and circulated amongst the law enforcing bodies, quasi-government sectors, such as the Duty Lawyer Service (DLS,) Legal Aid (LA) and the Hospital Authority (HA.) In addition, in recent years, the Judiciary interpreters' master list has been used by the Convention Against Torture (CAT) -

\footnotetext{
${ }^{1}$ Information received from the Judiciary via email, dated June 2013. Enquiry sought from the email address available on the Judiciary's website: http://www.judiciary.gov.hk/en/others/contactus.htm
} 
DLS office and the Removal Assessment Section (RAS) responsible for legally representing asylum seekers and assessing their claims respectively, under the Unified Screening Mechanism (USM.)

\subsection{Recruitment by the Judiciary previously and today}

From the early 80s until the late 90s, EM interpreters were unassessed and simply recruited through recommendation by consulates' offices, or fellow interpreters, or by legal professionals. No written guidelines were provided and some were even assessed informally by a colleague. The repercussions of such an arbitrary recruitment system resulted in a practice, whereby interpreters were asked to interpret in multiple regional languages and dialects, regardless of whether they could read and write in the language interpreted. Nevertheless, at the turn of the millennium, there was progressive transformation in the recruitment policy and vacancy announcements were made accessible to public. Interpreters were required to be university graduates or holders of an equivalent degree. Speaking and writing abilities were assessed either by personnel from a respective consulate's office, or by a senior interpreter in the language group for a native language and by a senior in-house court interpreter for the official languages.

To date, nothing much has been reformed regarding the recruitment procedures, except for the granting of registration. Previously, interpreters were put on probation for a few months before they could be registered by the Judiciary, thereby ensuring their names appeared on the master list and thus making their services available to other departments. In recent years however, interpreters have been required to work exclusively for the courts for a few years before receiving a registration number from the Judiciary. One of the reasons for such an arrangement seems to be the retention of interpreters solely for court assignments. Once registered, most interpreters prefer jobs with other departments, since it is less stressful and more flexible, unlike the courtroom arrangement. In addition, court work only guarantees payment for a minimum two hours, even though interpreters could have been booked for a whole day, or days. Such a practice has inadvertently developed into a pattern, whereby novice interpreters, or newly recruited interpreters, are sent to the courts and the experienced ones are engaged by the law enforcing bodies, or DLS, LA or other departments, with flexible working hours.

\subsection{Shortfall of training provisions}

In the last decade or so, the Judiciary has attracted academically qualified EM language speakers, although they are not necessarily trained in interpreting and translation. A handful of EM interpreters are trained overseas, or by local NGOs and the Hong Kong Baptist University (HKBU) ${ }^{2}$, while the majority are self-taught practitioners. The Judiciary does not provide a comprehensive training to parttime interpreters. The in-house (full time) Judiciary interpreters, who usually work alongside part-time interpreters, however, are academically qualified and trained ${ }^{3}$, as mentioned in the paper submitted to the "Panel on Administration of Justice and Legal Services Performance of Court Interpreters", $\mathrm{LegCo}^{4}$ in 2004. Translation and interpreting courses at a tertiary level are available in the official languages; however, no courses are available for ethnic minority groups. Although the Judiciary used

\footnotetext{
${ }^{2}$ A small group of interpreters, registered with the Judiciary were trained as trainers by Dr. Ester S.M. Leung at Hong Kong Baptist University (HKBU.) Interpreters were trained as a part of the research project undertaken by Dr. Leung. ${ }^{3}$ http://www.legco.gov.hk/yr03-04/english/panels/ajls/papers/aj0322cb2-1592-1e.pdf, retrieved 25 ${ }^{\text {th }}$ August 2015.

${ }^{4}$ Legislative Council of HKSAR http://www.legco.gov.hk/general/english/cmi/yr08-12/reg_0812.htm, retrieved 25 ${ }^{\text {th }}$ August 2015.
} 
to organise an-hour long workshop for interpreters once every few years in the past, there have been none since 2011. The content of the workshop focused mainly on registration for police record checks, a short presentation on interpreting and a brief discussion.

Currently, after passing the recruitment assessment, interpreters are provided with a few hours of induction on court procedures and the code of ethics, issued with a handbook containing a glossary of English legal terminology, court procedures and court addresses, and then sent to the courts for interpreting assignments. In addition, a period of court observation lasting for a few hours is organised for new recruits either before or after taking up a few court assignments. There are short courses offered by NGOs and the Employment Retraining Board ${ }^{5}$ (ERB) in community interpreting; these courses, however, are too general and not adequate to interpret in legal settings, the requirement being basic literacy in the languages interpreted. In contrast, a high level of language proficiency is essential for interpreting.

\subsection{Demand for interpreting service}

The interpreting service is in mounting demand, because of the escalating population of ethnic minorities in Hong Kong over the last two decades. According to the Population Census Report 2011 a total of 451,183 ethnic minorities, constituting $6.4 \%$ of the total population were residing in Hong Kong in 2011. Among them, ethnic population comprised Indonesians (29.6\%), Filipinos (29.5\%), Whites (12.2\%), Mixed (6.4\%), Indians (6.3\%), Pakistanis (4.0\%), Nepalese (3.7\%), Japanese (2.8\%), Thais (2.5\%), Other Asians (1.6\%), Koreans (1.2\%) and others $(0.3 \%)$. The majority of ethnic minorities in Hong Kong were regular residents (98.7\%) while only 5,918 (1.3\%) were mobile residents. The number of ethnic minorities in Hong Kong increased by a significant $31.2 \%$ over the past 10 years, from 343,950 in 2001 to 451,183 in 2011.

While the majority of the EMs are migrant workers, others, such as Indians, Pakistanis and Nepalese are residents in Hong Kong, an eventuality mainly associated with Hong Kong's colonial history (Erni and Leung 2014; Gillian 2009; Plüss 2005). In addition, an emerging phenomenon is the increasing number of asylum seekers in Hong Kong in the last 10 years, which is around $10,000^{7}$ at present. Comparatively, the groups requiring interpreting services may be low in ratio to the total EM population, as many are also highly educated groups, living as expatriates among the South Asian and East Asian communities, as well as people hailing from the other continents. The demand still exists nevertheless among the less educated groups, or people who have been educated in their mother tongue in their native countries.

\section{Identities of EM interpreters and cultural mitigation}

This paper explores the professional identity of interpreters that intertwines with their ethnic identities; their existence in Hong Kong, historical and economic dimensions and social perception of their status by the interpreters themselves, other professionals and laypersons present in triadic exchanges. It also studies how interpreters as well as professionals, working together, conceive incorporating cultural differences that occur in the speakers' utterances into interpreting. Cronin (2002) advocated for the

\footnotetext{
${ }^{5}$ http://www.erb.org/Corp/home/coz_eng_cit/en, retrieved 25 ${ }^{\text {th }}$ August 2015.

${ }^{6}$ http://www.census2011.gov.hk/pdf/EM.pdf, retrieved $25^{\text {th }}$ August 2015.

${ }^{7}$ http://qz.com/477021/photos-these-refugees-stuck-in-hong-kong-cant-get-asylum-cant-work-and-cant-leave/, retrieved $22^{\text {nd }}$ September 2014. No official data is made available so far.
} 
need within the discipline of Interpreting Studies (IS) to examine economic, political and cultural circumstances underpinning interpreting activities, as interpreters work across the boundaries of language, culture, gender, class, nationality, ethnicity and other relevant variables.

It is generally assumed that interpreters should be able to identify cultural differences, as they are aware of their native culture, as well as the dominant mainstream culture. Yet, whether an interpreter is a native speaker of the language he or she interprets and is actually accustomed to the mainstream working culture and systems in place, necessitates further investigation. Berk-Seligson (1990) exemplified hedging as one of the cultural manifestations, where roundabout talking or narrative-style speech are not regarded as evasive, but rather succinct, whereas direct and blunt expressions are considered rude in various dealings in Hispanic culture. Thus, a hedged narrative series of answers may not have a negative connotation of evasiveness to Hispanics.

Various researchers (Corsellis 2008; Hale 2007; Lee 2009; Ra 2013) have pinpointed the issues related to cultural differences and cultural invention in legal settings, the conflicting views of legal professionals and interpreters on cultural mediation, the need to examine how it is done by the interpreters and whether it is possible to integrate cultural meanings without intervening in court proceedings. Tallentire (2009), now listed as a District Court Judge, drawing upon his experience as a Magistrate of some 11 years in Hong Kong, opined how interpreters and clerks in his court assisted him to understand local culture and how cautious he was not to impose his western values on Hong Kong's "multi-racial" and "multi-custom" social structure.

His opinion is analogous with Morris (1995) who advocated providing some latitude to interpreters, allowing them to use their discretion, to take an active stance in attempting to convey meanings and intentions in the communication process of interlingual and intercultural mediation, against the legal preference of verbatim (word-for-word) interpretation. In her research, the legal professionals firmly stated that "when rendering meaning from one language to another, court interpreters are not to interpret - this being an activity which only lawyers are to perform, but to translate $[\ldots]$ the speaker's words verbatim" (ibid: 26).

\section{Research Methodology}

The initial plan for research methodology was drawn on the basis that audio recordings of trial hearings in Hong Kong law courts could be obtained for analysis. However, the Judiciary declined the request for the recordings, with no reasons given, despite the fact that earlier researchers, such as Leung and Gibbons (2007) and $\mathrm{Ng}$ (2013) have obtained recordings from the courts; none were in minority languages, however. Interpreting in the official languages has been known to be less problematic because of the bilingual professionals and spectators present in the courtrooms. Interpreters often get corrected by the judges or the legal professionals. The change of the Judiciary's decision on accessible data for research purposes indicated a much more conservative approach to the interpreting services provided to the ethnic minorities, which have been known to be controversial. The following are the research methods used in the current project:

\subsection{Social networking}

I have implemented Milroy's $(1987,2003)$ social networking approach to collect data via the interpreter-network that I have established through almost 9 years of my work as an interpreter. Social network analysis has been expansively employed by anthropologists and sociologists as a holistic approach to examine complex networks of social relations and network dynamics, revealing 
underlying meanings to a phenomenon (Barnes 1954, 1972; Barnett 2011; Wellman and Berkowitz 1988). Milroy's (1987) study covered the political situation in Belfast, in which the social network research method was the most appropriate one for her at the time, in order to find out the intricate relationships between different groups of people. Milroy and Gordon (2003) suggest a concept of how social network structure is a "boundless web of ties" of individuals engaged in interactions, influencing a repertoire of shared norms in social practice.

With regard to the identity formation of EM interpreters, I have looked into the dynamics of how each language group of interpreters work together at a micro level, in terms of professional information sharing amongst the group, as well as whether there are any overlaps or conflicts between the interpreters' ethnic and professional identities in interpreting practice.

\subsection{Ethnography}

Under the overarching principle of the social network approach, I have also employed critical ethnography (Madison 2005) to analyse how structural factors and systems in place impact upon interpreting practice. Critical ethnography is about critical analysis unravelling unfairness beneath the surface and a sense of moral obligation to address the issues of unjust practice, in order to challenge the status quo within a particular domain. Altogether 27 criminal cases were observed from June 2014 until May 2015, out of which, 25 were trial cases, whereas 2 were appeal hearings at the high court. All the cases observed were in courts open to public and the clerks sitting in the courts had been notified before the observation.

\subsection{Semi-structured interviews with interpreters}

One-on-one, semi-structured, in-depth interviews with 20 Judiciary registered EM language interpreters were conducted. Professionally known interpreters of various language backgrounds were approached for the interviews. The questions revolved mainly around their background, reasons for joining the interpreting industry, identification with interpreting practice in Hong Kong, their views on the quality of interpreting services and their particular experience on cultural mitigation/intervention at work. All the interviews have been audio-recorded and transcribed.

\subsection{Semi-structured questionnaire for legal professionals}

Using snowball sampling (Browne 2005), a technique used in social science researches to start collecting data through the social network, 39 semi-structured questionnaires were circulated among the solicitors and barristers electronically and in person, out of which, 24 were returned completed. Since the selection of informants is critical to the reliability of the data collected, as some lawyers have seldom worked with interpreters, I have made use of my own experience by sending the questionnaires to those solicitors and barristers known to have prominent recognition within the legal sector and with rich experience of working on cases that involved EM defendants and EM language interpreters. 


\subsection{Semi-structured questionnaire for government service providers or users}

Information had been sought from the Judiciary, as well as government departments, regarding the interpreting service provided by interpreters in Hong Kong. The Judiciary's Part-time Interpreters' Unit, was approached for an interview or survey questionnaire, however the request was declined. Later, a semi-structured questionnaire was sent to the DLS for the CAT office, the RAS of the Immigration Department, Legal Aid (LA) and the Hong Kong Police Force. The questionnaire consisted of 8 questions relating to interpreters' professional identity, their role, performance, knowledge of legal concepts and procedures, interpreting techniques, monitoring mechanisms and guidelines. The only completed questionnaire was received from the RAS-Immigration. The low rate of participation from government departments, despite them having high usage of interpreting services, seems to demonstrate their lack of interest in research, or the inability to prioritise interpreting services in EM languages, among other reasons.

\subsection{A semi-structured interview with a service recipient}

An interview was conducted with a service recipient who has been a resident in Hong Kong for the last 18 years and who has been a user of the interpreting service throughout this time. Although an interview with a single service recipient did not provide any conclusive data, it did help to explore the interpreting service through the lens of a service recipient.

\subsection{An online survey for interpreters}

The online survey was released exclusively to interpreters to ensure maximum participation of practising interpreters. It was released through informal social network platforms created by the interpreters themselves and made easily accessible by the usage of smart phones in recent years. The interpreters not in these social network groups were sent online survey links through available electronically mediated communication channels.

The online survey was open for a month, with the response rate of around 10 percent. From a quantitative research perspective, 10 percent is affirmatively at the lower end, with Bryman (2012) suggesting an online survey requires a 70 percent response for reliability and validity of research; however, data producing extremes, as in the current case, can be sufficient for comparative analysis and qualitative exploration (Yin 2014). This low response seems to demonstrate the interpreters' lack of interest in research, risk of the exposure that such research results might trigger, or the availability of the limited number of interpreters who believe in quality and professionalisation of the interpreting services. 


\section{Theoretical framework}

\subsection{Identity}

Identity, studied across almost all social science disciplines, relates to who we are and with whom and with what we identify. Identity is expounded as a linkage between the individual and the social (i.e. how I see myself and how others see me), demarcation by similarities and differences, one's active engagement in negotiating tension between the human agency and social structure, as well as existence of single or multiple identities being fixed, or fluid and transformative (Burke and Stets 2009; Elliott 2011; Giddens 1990; Goffman1972,1984; Jenkins 2004; Schwarzbaum 2011; Spencer 2006; Taylor and Spencer 2004; Woodward 2000). In analysing identity construction, I have adopted Jenkins' $(2004,2008)$ theoretical model of internal-external dialectic, which focuses on the reciprocation of the self (group identity) and the other (external factors) and also gives prominence to the role of the institution, social world, structure/practice, in the process of identity formation.

Jenkins draws on Barth (1969) to incorporate the idea of boundaries, which are delineated by the concept that identity is not only to be signalled, but has to be accepted by the other before it can be embodied. Hence, identities are negotiated in these boundaries of persistence, resistance and acceptance, which work interactively between the internal-external dialectic of identification. An example could be the institutional power in categorising and allocating resources for the benefit of a group; how that group perceives it in return, or vice versa and how such a step impacts the identity formation of the group.

Group identification takes place through shared meanings and practices, which is then recognised and enforced by institutionalised practices and which are either, accepted, negotiated or resisted by individuals or groups. The identification and categorisation work between the three submerged orders: individual, interactional and institutional signify the processes of ethnic identification, where the flow is bidirectional.

\subsection{Incorporating cultural differences into interpreting}

I have supplemented Jenkins' model with Neuliep's (2009) contextual approach to intercultural communication, in order to analyse how interpreters integrate identified cultural differences. The model attempts to explain intercultural communications through various interdependent contexts depicted through concentric circles, namely, cultural context, micro-cultural context, environmental context, perceptual context and sociocultural context.

In the model, cultural context denotes a larger milieu or a mainstream practice, society, government or nation. Within cultural context remains a microcultural context, that is to say, subcultures or group identification, such as ethnic groups. Within it, remains environmental context, which is one's immediate surroundings where the communication takes place; for instance, the work place. Then, comes the perceptual context that refers to one's perception towards others in interaction, whereas sociocultural context emerges in interaction between people from different cultures through verbal and nonverbal cues. Although these contexts seem nebulous in a real situation, a particular context does constrain and influence the context encircled and the ubiquity of the cultural context and the dominance it can exert in communication cannot be denied. The model also examines the hierarchical existence of a subordinate status of the microcultural groups within the dominant group, where the dominant mode of expression as a preferred language contributes to the subordination of the microcultural groups. 


\section{Findings}

\subsection{Identity in question:}

Although the majority of interpreters consider themselves to be professionals, the exception is those working part-time, who consider themselves non-professionals due to the lack of proper accreditation in interpreting and translation in Hong Kong. There are varying factors conducive to the formation of a more equivocal status, which are discussed in the following:

\subsubsection{Lack of stringent recruitment, training and monitoring}

The need for rigorous assessment in recruitment has been advocated by many interpreters. Lack of professional development courses for these interpreters has resulted in a compromise of quality service and violation of the code of ethics, in particular by stepping out of the interpreters' role. Interpreters have reported to have understood very little due to a lack of knowledge of legal proceedings, legal concepts and systems in place when they first started, which conspicuously shows a practice of guess work, supplemented by the trial and error method. Likewise, lack of proper monitoring by the Judiciary and various employing departments, and the implementation of appropriate disciplinary actions, have contributed to negative generalisations and tarnished the professional image of interpreters.

\subsubsection{Interpreters' stance}

For a considerable period, interpreters have been trying to get organised as a group in terms of information sharing and discussions in various languages and are known to have conducted signature campaigns for a pay increment, resulting in the practice of automatic increments in recent years. Many interpreters see the need for a professional body to be formed by the interpreters, working for the Judiciary. This would enable them to act collectively, so that they stand a better chance of negotiation with the Judiciary and government departments. Differences of opinion and a lack of solidarity among the interpreters have been observed to be an impediment to the establishment of a body with a legal entity.

\subsubsection{Inconsistencies and irregularities}

One of the irregularities observed is the payment practice. Although an interpreter may get booked for a full day, his or her payment is determined by the actual number of hours worked, which is highly dependent on the attendance of the service recipient and circumstances beyond an interpreter's control. Interpreters consider it to be an unfair policy. A similar practice exists for last minute cancellations, 
which are made around $6 \mathrm{pm}$ for the appointment fixed for next morning, or in the morning for an appointment fixed for the same afternoon or, worse still, an hour before the appointment, by which time the appointed interpreter would already be on the way or even in the vicinity of the work place by then. Though these occur quite frequently, none of the departments have a policy to address it and payments in such cases are dealt with at the discretion of the officer involved.

\subsubsection{Changing perceptions}

Interpreters have traditionally been perceived as a mere language converters of the message uttered by the speaker, drawing minimum attention to the self, although the invisible self of the interpreter has been challenged by the scholars (Angelelli 2004; Hale 2007; Metzger 1999; Morris 1995; Roy 1993; Tate and Turner 1997; Wadenjsö 1998) in favour of "co-participation" and "co-construction," as opposed to a mechanical relaying of messages. The same concept of a passive message conveyer is largely expected of interpreters, but interpreters are increasingly found to be vocal and organised when it comes to their rights to fair treatment, or the rights of the service recipient on humanitarian grounds.

The constant negotiation and tensions between the interpreters and authorities, in its entirety, demonstrates the phenomenon of a process of identity construction for the interpreters. This is based on both positive and negative attributes, their nationalities and languages interpreted, professional recognition, as well as professional service rendered. The identity formation of interpreters, which commenced with an arbitrary recruitment of bilinguals to cater to legal needs in the early 80s, continues to build today, with a high demand for professional services and supply of interpreters in multicultural Hong Kong. Interpreters struggle for professional recognition, which can only be achieved through accreditation, rigorous assessment, training, monitoring, evaluation and feedback, as well as better remuneration. Nevertheless, such recognition cannot be attained without intervention by the authorities, in order to ensure quality control, as well as professional treatment in terms of remuneration and attitude towards interpreters in the work place.

\subsection{Incorporating cultural differences}

Incorporating cultural differences has been found to be one of the most challenging acts for interpreters, as it is directly linked with the role of interpreters and the code of ethics. It requires interpreters to add or introduce something, which has been only indirectly hinted at or spoken about in veiled speech, if taken literally. Even though the majority of interpreters claim to have intervened, or explained in various legal settings and think it is unavoidable, a few veteran interpreters with decades of experience opined that it is forbidden within the courtroom setting, as it goes beyond the established function of verbatim interpreting. From the observation of cases and with only a few exceptions, the majority carried on with the flow of interpreting, focusing on the words and completely relying on the legal professionals to figure out the meanings, if any.

From observations, interviews with interpreters, questionnaires with legal professionals, as well as RAS, it is concluded that the context or the situation governs to a considerable extent whether interpreters incorporate cultural differences. Interpreters have been found to be reticent when it comes to intervening or providing explanations, because of the DARTS (Digital Audio Recording Transcription Services) in place and the power imbalance situated within the constriction of a courtroom setting, where interpreters are expected to interpret only what has been said by the speaker. Other than the courtroom setting, interpreters claim to have explained any cultural differences 
identified to the concerned parties in all legal settings, with the exception to RAS, which stipulates that the interpreters interpret "verbatim in direct speech".

Legal professionals' views on incorporating cultural differences demonstrate a conflicting expectation when analysed in conjunction with the expected roles of interpreters, as shown in figure 1 and 2. Interpreters' expected roles strongly link how utterances relating to cultural differences can be dealt with, while the majority opined that interpreters should explain any utterances, some still held the view of leaving aside probing and explaining tasks to the legal professionals.

Figure 1

\section{Legal professionals' view on clarifying cultural differences}

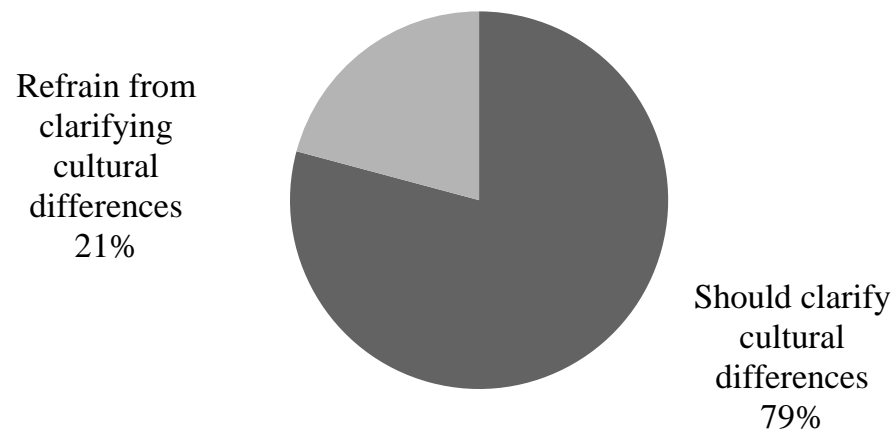

Figure 2

\section{Legal professionals' views on interpreters' roles}

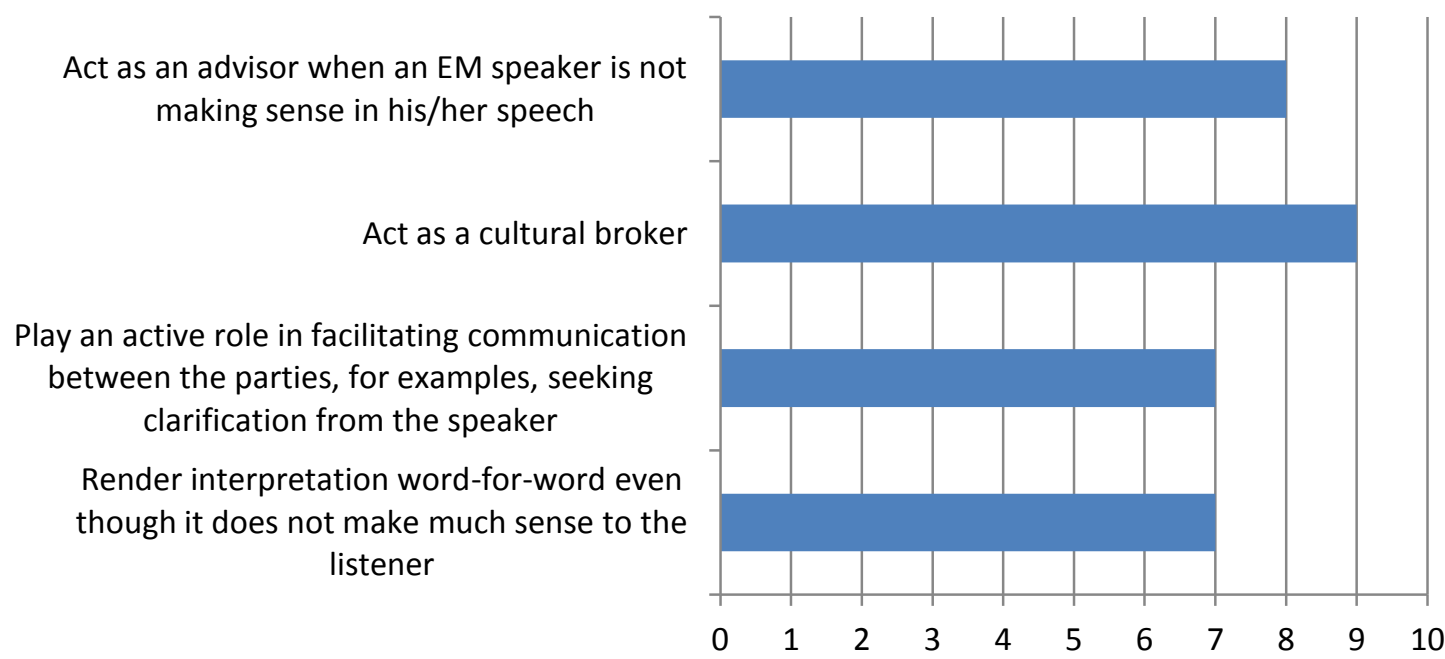

It is concluded that the setting, or context, are the decisive factors that guides interpreters to include cultural differences identified through verbal and non-verbal codes. To a novice interpreter, the hierarchical structure of the courtroom is immensely overwhelming, both in the form of the language 
used and the systems in place. The interpreter interpreting in a minority language needs to be empowered through training, comprising components on legal concepts and procedures, ethical incorporation of culturally loaded terms and mainstream work culture, particularly in legal settings, so that an interpreter stands firm in his/her role and responsibilities while interpreting and dealings with service providers, instead of making speculations based only on the written guidelines received and taking a compromising perspective.

\section{Conclusion}

To summarise, on the one hand, EM interpreters in Hong Kong have a unique professional identity, that of both experienced and inexperienced, highly qualified and less qualified, as well as trained and untrained interpreters. On the other hand, little has been done by the Government to enhance the quality of service by professionalising the service industry and ensuring that proper mechanisms are put in place with regard to assessment, training, accreditation, evaluation and feedback. The demand for interpreting services is recognised, but the status quo of the interpreters is ignored.

These facts can be condensed to the issue of the status quo of EM interpreters' professional identity; whether it is linked to their EM identity and the fact that their exclusion from professional development opportunities is in any way associated with their EM status in Hong Kong. Likewise, many interpreters ought to think that cultural mitigation is indispensable, as interpreting is based on meanings and intentions, not only words. There are interpreters who are proponents of verbatim interpretation within the courtroom, signifying a divisive practice. Although the general assumption is that an EM interpreter is able to identify cultural differences, whether one is able to identify and would include such differences into interpreting is contentious. It calls for proper directions by the Judiciary or other bodies issuing guidelines to ensure a standardised practice.

\section{Acknowledgement}

I would like to express my sincere gratitude to Dr. Ester S.M. Leung and the two independent reviewers for their invaluable comments on the earlier versions of this paper.

\section{8. $\quad$ References}

Angelelli, Claudia V. 2004. Revisiting the Interpreter's Role. Amsterdam: John Benjamins.

Berk-Seligson, Susan. 1990. The Bilingual Courtroom: Court Interpreters in the Judicial Process. Chicago: The University of Chicago Press.

Barth, Fredrik. ed. 1969. Ethnic Groups and Boundaries: The Social Organization of Culture Difference. Oslo: Universitetsforlaget.

Barnes, John Arundel.1954. Class and Committees in a Norwegian island parish. Human Relations 7: $39-58$.

Barnes, John Arundel.1972. Social network. Addison-Wesley Module in Anthropology 26: 1-29.

Barnett, George A. 2011. Encyclopedia of Social Networks. California: Sage. 
Browne, Katherine. 2005. Snowball sampling: using social networks to research non-heterosexual women. International Journal of Social Research Methodology 8 (1): 47-60.

Bryman, Alan. 2012. Social Research Methods. Oxford: Oxford University Press.

Burke, Peter J., and Jan E. Stets. 2009. Identity Theory. Oxford: Oxford University Press.

Corsellis, Ann. 2008. Public Service Interpreting: The First steps. New York: Palgrave Macmillan.

Cronin, Michael. 2002. The empire talks back: orality, heteronomy and the cultural turn in Interpreting Studies. In The Interpreting Studies Reader. Ed. Franz Pöchhacker, and Miriam Shlesinger, 386-397. New York: Routledge.

Elliot, Anthony. ed. 2011. Routledge Handbook of Identity Studies. New York: Routledge.

Erni, John Nguyet, and Lisa Yuk-ming Leung. 2014. Understanding South Asian Minorities in Hong Kong. Hong Kong: Hong Kong University Press.

Gillian, Bickley. ed. 2009. A Magistrate's Court in Nineteenth Century Hong Kong. Hong Kong: Proverse.

Giddens, Anthony. 1990. The Consequences of Modernity. UK: Polity Press.

Goffman, Erving. 1972. Interactional Ritual. Harmondsworth: Penguin.

Goffman, Erving. 1984. The Presentation of the Self in Everyday Life. London: Pelican.

Hale, Sandra Beatriz. 2007. Community Interpreting. Hampshire: Palgrave Macmillan.

Herbert, Jean. 1952. The Interpreter's Handbook: How to Become a Conference Interpreter. Geneva: Georg.

Jenkins, Richard. $2^{\text {nd }}$ ed. 2004. Social Identity: Key Ideas. London: Routledge.

Jenkins, Richard. $2^{\text {nd }}$ ed. 2008. Rethinking Ethnicity. London: Sage Publications.

Lee, Jieun. 2009. Conflicting views on court interpreting examined through surveys of legal professionals and court interpreters. Interpreting 11 (1): 35-56.

Leung, Ester S. M. and John Gibbons. 2007. Purposes, roles and beliefs in the hostile questioning of vulnerable witnesses. In The language of sexual crime, ed. Janet Cotterill, 139-158. Basingstoke: Palgrave Macmillan.

Madison, Deidra Soyini. 2005. Critical ethnography: method, ethics, and performance. California: Sage.

Metzger, Melanie. 1999. Sign Language Interpreting: Deconstructing the Myth of Neutrality. Washington DC: Gallaudet University Press.

Morris, Ruth. 1995. The Moral Dilemma of Court Interpreting. The Translator 1 (1): 25-46.

Milroy, Lesley. $2^{\text {nd }}$ ed. 1987. Language and Social Networks. Oxford: Basil Blackwell Ltd.

Milroy, Lesley, and Matthew Gordon. 2003. Sociolinguistics Methods and Interpretation. Oxford: Blackwell Publishing.

Neuliep, James W. $5^{\text {th }}$ ed. 2009. Intercultural Communication: A Contextual Approach. California: SAGE publications.

$\mathrm{Ng}$, Eva. 2013. Who is speaking? Interpreting the voice of the speaking in court. In The Critical Link 6: Interpreting in a Changing Landscape, ed. Christina Schäffner, Krzysztof Kredens and Yvonne Fowler. 249-266. Amsterdam: John Benjamins.

Plüss, Caroline. 2005.Migrants from India and Their Relations with British and Chinese Residents. In Foreign Communities in Hong Kong, 1840s-1950s. Ed. Cindy Y. Chu, 155-170. New York: Palgrave Macmillan.

Ra, Sophia. 2013. Community interpreting: Asian language interpreters' perspectives. Translation \& Interpreting 5 (2): 45-61.

Roy, Cynthia.B. 1993. The problem with definitions, descriptions, and the role metaphors of interpreters. In The Interpreting Studies Reader. Ed. F. Pöchhacker and M. Shlesinger, 344353. London: Routledge.

Spencer, Stephen. 2006. Race and Ethnicity: Culture, Identity and Representation. London: Routledge. Song, Miri. 2003. Choosing Ethnic Identity. UK: Polity Press and Blackwell Publishing.

Schwarzbaum, Sara E., and Thomas, Anita Jones. $2^{\text {nd }}$ ed. 2011. Culture and Identity: Life Stories for Counselors and Therapists. London: SAGE Publications.

Tallentire, Garry. 2009. The Hong Kong (Police) Magistrate in the 1880s and 1990s: A Flavour of the Times. In A Magistrate's Court in Nineteenth Century Hong Kong: Court in Time, ed. Gillian Bickley, 133-143. Hong Kong: Proverse Hong Kong. 
Taylor, Gary, and Steve Spencer. ed. 2004. Social Identities: Multidisciplinary Approaches. London: Routledge.

Tate, Granville, and Graham H. Turner. 1997. The code and the culture: sign language interpreting- in search of the new breed's ethics. In The Interpreting Studies Reader. Ed. F. Pöchhacker and Miriam Shlesinger, 372-383. New York: Routledge.

Wadenjsö, Cecilia. 1998. Interpreting as Interaction. London and New York: Longman.

Wellman, Barry and Stephen D. Berkowitz. ed. 1988. Social structures: a network approach. New York: Cambridge University Press.

Woodward, Kath, ed. 2000. Questioning Identity: gender, class, and nation. London: Routledge.

Yin, Robert K. 2014. Case study research: Design and methods. Thousand Oaks, CA: Sage. 